Универзитет у Београду https://doi.org/10.18485/ai_lik.2020.6.9.2 Филолошки факултет e-mail: marko.cudic@gmail.com

\title{
ТЕОРИЈА И КРИТИКА ПРЕВОДА У ЧАСОПИСУ НİD ОД 1972. ДО 1991. ГОДИНЕ
}

Новосадски књижевни часопис Híd је током осамдесет и пет година свог постојања израстао у најзначајније књижевно и културно гласило војвођанских Мађара. Поред праћења актуелне мађарске књижевне продукције у Војводини, часопис редовно објављује и преводе из савремене српске књижевности. Циљ овог рада јесте да пружи систематски хронолошки преглед транслатолошких текстова на страницама овог часописа у периоду од 1972. до 1991. године.

Кључне речи: књижевни часопис Hid, научна и есејистичка мисао о превођењу.

1 Овај чланак представља скраћену и модификовану верзију ауторове студије објављене на мађарском језику под насловом „Fordításelmélet, kritika és kommentár a Híd ban a hetvenes évek elejétől napjainkig. Kronológiai áttekintés, megjegyzésekkel”у зборнику радова прочитаних на међународном научном скупу посвећеном осамдесетогодишњици постојања новосадског књижевног часописа на мађарском језику Híd одржаном 14. децембра 2014. године. У: Faragó Kornélia (уредник), Mozgalom, kultúraformálás, irodalmi gondolkodás. Tanulmányok a Híd történetéből, Forum Könyvkiadó, Ujvidék [Нови Сад] - Vajdasági Magyar Müvelödési Intézet, Zenta [Сента], 2014, стр. 168-184. Ова, скраћена и модификована српска верзија поменутог рада настала је као резултат ауторовог учешћа на научном пројекту Улоїа срйске йериодике у формирағу книжевних, кулимурних и националних образаца (178024) Министарства просвете, науке и технолошког развоја Србије, који се реализује у оквиру Института за књижевност и уметност у Београду. 
Познати новосадски књижевни часопис на мађарском језику Híd (Хид/Мост), још од свог оснивања тридесетих година двадесетог века, као један од својих главних циљева истакао је зближавање југословенске (а у оквиру ње, наравно, и српске) и мађарске културе, како, уосталом, сугерише и само име часописа. Требало би ипак, ради избегавања забуне, нагласити да овај часопис није превасходно специјализован за преводну књижевност, већ за књижевну продукцију Мађара, како оних војвођанских, тако и књижевника из Мађарске. Ипак, од самог свог оснивања није изашао ниједан број овог часописа а да се у њему није нашао бар један превод песме, приче или есеја неког југословенског писца.

Након Другог светског рата, а у складу са званичном политиком „братства и јединства“ та тенденција само је још појачана. Ипак, овај часопис је имао ту срећу да су га током послератних деценија уређивали врхунски писци, научници и интелектуалци, попут Михаља Мајтењија, Имреа Борија, Кароља Ача, Јаноша Бањаија и других, па је селекција приспелих рукописа била врло ригорозна - критеријум готово никада није био идеолошка подобност аутора, већ искључиво квалитет рукописа. Штавише, главни уредник Јанош Бањаи je, рецимо, показао значајан степен грађанске храбрости када ce, у време незапамћене хајке на Данила Киша поводом књиге Гробнииа за Бориса Давияовича недвосмислено ставио на Кишову страну. Такође ваља истаћи да часопис, веран својој предратној левичарској традицији, никада није гајио конзервативан књижевни укус, напротив. На његовим страницама нашли су се не само преводи југословенских и српских класика, већ и таквих неоавангардиста и бунтовника, какви су били, рецимо, Војислав Деспотов и Вујица Решин Туцић.

Могуће је да та осетљивост и тај слух за истинске књижевне величине и вредности, тај истанчани поетички, естетски и морални укус и став неколицине најзначајнијих уредника часописа Híd потиче не само из њихове одиста широке културе и подразумеване мађарско-српске двојезичности, већ и из нечега што је велики филозоф Пол Рикер у разговору с једним својим младим мађарским колегом одредио као својеврсну „културалну двојезичност“, у смислу једне 
дубинске и суштинске отворености према Другом. (Tóth 2010: 150). Изгледа да је ова врста рикеровски схваћене „културалне двојезичности“ која није наметнута споља, красила, а и данас краси уреднике овог часописа.

Међутим, с обзиром на количину преведених текстова при чему имам у виду „само“ преводе српске књижевности у осамдесет шестогодишњој историји овог часописа - сасвим је извесно да би само пуко набрајање имена преведених аутора превазишло границе, а и намену једног овако замишљеног чланка. Циљ овог прегледног рада јесте стога осврт на оне малобројније текстове у часопису Híd који се баве самим чином превођења, дакле, транслатолошким проблемима, било у виду теоријско-есејистичких, било у виду критичко-аналитичких чланака. Појава таквих текстова поклапа се са јачањем транслатологије као филолошко-лингвистичке дисциплине у свету. Први озбиљнији текстови ове врсте биће у часопису Híd објављени почетком седамдесетих година двадесетог века, у време када је главни уредник овог часописа био песник и преводилац Карољ Ач (Ács Károly, 1928-2007). Та тенденција вероватно није случајна, ако имамо у виду да је Карољ Ач, поред властитог, врло значајног, песничког опуса на мађарском језику, остварио и запажен паралелни опус у виду препева песама југословенских песника.

Први текст транслатолошког типа објавио је Тибор Пап (Papp Tibor) под насловом Кюижевност̄ језика̂ - језик кюижевностии. ${ }^{2}$ Он у свом тексту одлучно одбацује концепт књижевног превођења као културног трансфера: „(..) ширење културе није задатак књижевника“, тврди Пап. ${ }^{3}$ (Рарр 1972: 652). Пап сматра да превођење мора бити терен за људе доказаног књижевног дара, израженог естетског укуса и уметничког сензибилитета. Он оштро критикује, по његовом мишљењу, погрешно схваћено начело преводилачке верности и залаже се за оно што ће, у светским оквирима отприлике

2 Наслови свих текстова мађарских аутора, ради уштеде простора, овде су преведени на српски (превод је мој - М. Ч.). За детаљније филолошке податке са оригиналним насловима текстова видети у

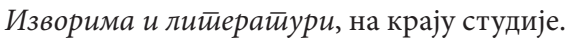

3 Сви преводи мађарских цитата су моји. (М. Ч.). 
у исто време, Јуџин Најда назвати „динамичком преводилачком еквиваленцијом.“ (Рарр 1972: 654). Тибор Пап уочава трагедију мањих култура, која се на плану превођења огледа у томе што наше (и мађарске и српске) класике на велике западне језике по правилу не преводе врхунски ствараоци, па чак ни филолози са стручним знањем наших језика и култура, а којима је матерњи језик управо тај на који преводе, већ да, напротив, врхунска књижевна дела настала на мађарском, српском и другим, условно речено, мањим језицима средње и источне Европе и Балкана, на велике, „светске“ језике по правилу преводе писмени, но језички и културолошки недовољно верзирани емигранти нашег порекла. У томе, а не само у пословичној културној надмености великих култура и њиховој суштинској незаинтересованости, требало би, по мишљењу Тибора Папа, тражити разлоге за депримирајућу чињеницу да огроман корпус значајних дела са ових простора на Западу пролази суштински незапажено, без озбиљније критичке рецепције. (Рарр 1972: 658-659).

Годину дана касније, дакле 1973. године, поводом сто педесете годишњице рођења великог романтичарског песника Шандора Петефија (Petőfi Sándor, 1823-1849), објављена је збирка одабраних српских препева Петефијевих песама у избору Младена Лесковца. На објављивање ове збирке промптно је реаговао српски хунгаролог, преводилац и теоретичар превода Сава Бабић (1934-2002). Његов текст није, међутим, класичан приказ књиге, већ се он у њему упушта и у прилично минуциозну анализу одређених преводилачких решења, нарочито оних из пера врсних песника Ивана В. Лалића и Данила Киша, покушавајући кроз такву упоредну алализу да укаже и на различитост њихових преводилачких поетика. Бабић истовремено одбацује кредибилитет превода „из друге руке“ и наглашава да је тај метод превођења данас већ превазиђен, мислећи, при томе, на чињеницу да Иван В. Лалић не зна мађарски, те да је радио из йоgсйрочника које су му припремали други преводиоци, често и сам Киш. (Babić 1973: 19). Да је часопис био отворен за конструктивну полемику, другим речима, да је дозвољавао да нека студија добије и своју, борхесовским речником формулисано, 
„контрастудију“, најбоље показује текст Песничке иаралеле Имреа Сича (Szücs Imre, 1935-1991) из следеће, 1974. године, у којем се Сич упушта у полемику са Бабићем. Он, наиме, тврди, управо супротно од Бабића, да непознавање изворног језика у смислу неразумевања текста, али слушања звука и ритма оригинала, заправо представља $\bar{u} р е g н о с \bar{u}$ за преводиоца. У том смислу, по Сичевом мишљењу, нека преводилачка решења Ивана В. Лалића боља су, песничкија су од Кишових. (Szücs 1974: 355-357). Треба, наравно, имати на уму да је Киш у то време био релативно млад писац и да још није био изградио себи ону врсту несумњивог списатељског и преводилачког ауторитета који ће га красити у наредне две деценије, па је и са те стране занимљиво читати ову критику његовог преводилачког поступка.

Септембра 1975. часопис ће објавити важну компаративистичку студију академика Имреа Борија (Bori Imre, 1929-2004) под насловом Уметиносй Иве Анgрића у оїлеgалу мађарске книжевностии. У њој се Бори детаљно бави преводима Андрићеве младалачке лирике из циклуса Ex Ponto, Немири и Шйа санам и шйа ми се gоїађа. Те преводе је, по Боријевом мишљењу, већ двадесетих и тридесетих година веома зналачки и надахнуто урадио Корнел Сентелеки (Szenteleky Kornél, 1893- 1933). Сентелеки, по Боријевом мишљењу, није упао у замку типичну за мађарске модернисте, естете окупљене око будимпештанског часописа Nyugat (Запад) да по сваку цену у преводу ствара римоване песме чак и ако рима у оригиналу нема. (Bori 1975: 802).

Наредне, 1976. године, Ласло Вегел (Végel László, рођен 1941.) у тексту под насловом Нaga йобуюеноі човека оштро критикује мађарски превод Крлежиног романа $\mathrm{Ha}$ рубу $\bar{u} а м е \bar{u} u$. Тај превод дело је познатог и прилично цењеног преводиоца Золтана Чуке (Csuka Zoltán, 1901-1984) који се, међутим, по Вегеловом мишљењу, није најбоље снашао у колоплету Крлежиних дугих, вијугавих реченица: „Крлежа се, наиме, често служи и за хрватски језик неуобичајеним синтаксичким конструкцијама и редом речи. Мађарски преводилац то систематски исправља, чини текст језички правилнијим. Јасно је да нас ови примери упозоравају на то да 
би, зарад поштовања преводилачке делатности, струка требало да организује конференцију о књижевном преводилаштву на којој би се оценио квалитет књижевних превода у протеклим деценијама.“" (Végel 1976: 1354). Вегел у својој критици пребацује Чуки и то што знаке навода не користи на истим местима као Крлежа у оригиналу, а познато је да наводници у прозном тексту, а посебно код Крлеже, често имају функцију иронизације. (Végel 1976: 1352).

Годину дана касније објављена је још једна значајна компаративистичка студија из пера Имреа Борија, под насловом Енgре Agи у срйскохрвайској книжевносиии (1906-1944). У овом хронолошком прегледу Бори полази од првих превода Адијевих песама које је на овим просторима, уз пропратну студију, својевремено објавио Тодор Манојловић. Чињеницу да је строго римоване Адијеве песме Манојловић преводио у прози, Бори објашњава Манојловићевим модернистичким, „француским“ преводилачким маниром и неком врстом негације Змајеве преводилачке технике: „Ако је Змај »посрбио« Арањевог Толguјy, Манојловић би, руковођен западним узорима, рационализовао песму одабрану за превођење, »тумачећи« само вербални смисао песме.“(Bori 1977: 56-57). У малобројним преводима Адијевих песама из пера Милоша Црњанског Бори примећује песникову-преводиочеву жељу да кроз превођење обнови језик српске поезије. (Bori 1977: 64). Мирослава Крлежу и његове преводе Адијевих песама које су, заправо, послужиле само као илустрација за Крлежину студију о Ендреу Адију, пак, Имре Бори види као еклатантан доказ да је овај велики хрватски модерниста песничко превођење доживљавао као изазов, као артистички задатак (Bori: 66-67), те је стога и у контексту Крлежине песничке конституције повремено функционално одступање од смисла оригинала оправдано. (Bori 1977: 68).

Исте, 1977. године, текстом из области практичних, рекло би се „занатских“ (у најбољем, а не ироничном смислу те речи) промишљања из области историје српске преводне књижевности, на страницама овог часописа поново се јавља Сава Бабић, студијом под насловом Велько Петировић као йревоgилаи, с мађарскоі, у којој овај српски хунгаролог указује 
на то да се Вељко Петровић, за разлику од својих претходника и савременика, кад је превођење с мађарског у питању, определио више за прозу него за поезију, будући и сам доминантно прозни писац. Кроз анализу Петровићевих превода мађарске прозе, Сава Бабић, међутим, долази до занимљивог открића, које може послужити и као препорука младим преводиоцима у процесу учења. Он, наиме, примећује да се Вељко Петровић при превођењу мађарске прозе - у којој постоји апсолутна доминација приповедачког перфекта веома креативно служи комбинацијама различитих глаголских времена које српски језик и традиција српске прозе омогућавају. (Babić 1977: 1230).

Уследића подужа, шестогодишња пауза кад је реч о транслатолошким текстовима на страницама часописа. 1983. године Ђерђ Пап (Papp György, 1941-2009) објављује студију под насловом Баш необичан йоклон у којој оштро, али аргументовано критикује мађарски превод језички и стилистички изузетно захтевног романа Пейријин венаи Драгослава Михаиловића. Мађарски преводилац романа, у овом чланку већ поменути и цитирани Имре Сич, по мишљењу Ђерђа Папа, показао се као апсолутно недорастао задатку, јер уопште није успео да у преводу пренесе једну од главних поетичких одлика овог романа засновану на употреби нестандардног дијалекта и говорног језика. (Рарр 1983: 527). Осим тога, Пап указује и на то да Сич на више места флагрантно крши преводилачку етику, употребљавајући у преводу романа - без ознаке! - нека ранија преводилачка решења који је у преводима одломака овог романа објављиваним у мађарској књижевној периодици користила Маријета Вујичић (Vujicsics Marietta). (Рapp 1983: 530).

Проблемима преводилачке етике бави се и Сава Бабић

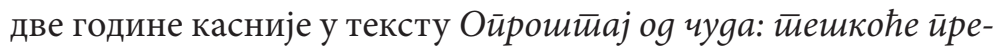
вођена „стиваралачких“ иитиайа. У овој студији Сава Бабић бави се проблемима превођења старогрчких цитата у драмама савременог писца Миклоша Хубаија (Hubay Miklós, 1918-2011). Приликом превођења цитата из, примера ради, Софоклових драма, стандардни поступак био би да преводилац пронађе релевантан српски или евентуално хрватски 
превод и употреби онај који у датом контексту највише одговара. Сава Бабић, међутим, упозорава на то да је проблем са Хубаијевим драмама у томе што Хубаи често намерно изврће и мења цитате из Софокла - или напросто у томе што су мађарски преводиоци другачије разумели изворни текст од српских - чиме би употреба канонизованог превода променила смисао датог места у Хубаијевој драми. Због тога Сава Бабић предлаже да, изузетно у оваквим случајевима, преводилац може одступити од стандардне преводилачке етике у превођењу цитата, наводећи примере из властите преводилачке радионице када му српски и хрватски преводи античких драма нису одговарали у датом контексту, па је био принуђен да преводи с превода, тачније, да преведе с мађарског тај део текста. (Babić 1985a: 377-385).

1985. година била је, такође, и година јубилеја - славила се стогодишњица рођења великог мађарског модерног класика Дежеа Костолањија (Kosztolányi Dezső, 1885-1936). Тим поводом, Ђерђ Пап се јавио текстом под насловом Роман „Шева“ у йуђини. Поуке из истиорије ирревоgа - срисккохрвайски йревоg јеgної Косииоланијевог романа. Пап у свом већ устаљеном маниру оштро и аргументовано критикује дотад једини српскохрватски превод Костолањијевог романа Шева (Pacsirta) из пера Стевана Летмањија (Létmányi István), наводећи да преводилац не увиђа значај снажног наноса лиричности у Костолањијевој прози, лиричности која се протеже од најмање, наизглед најбезначајније слике па до целине текста. (Рарp 1985: 1358-1359). Закључујући да је овај превод застарео, Пап наглашава потребу за новим преводом, који би широј југословенској публици отворио просторе нових тумачења Костолањијевог дела. (Рарр 1985: 1362).

Та иста, 1985. година, била је необично богата текстовима у којима се износе теоријска промишљања о превођењу. У такве текстове спадају и два приказа, слободно се може рећи, капиталне збирке коју је одабрао, саставио и превео Карољ Ач. Реч је о великој антологији препева песничких дела из неколико векова јужнословенских књижевности под насловом A kiásott kard (Ископана сабља). Оба приказа ове антологије објављена су у новембарском броју часописа 
Híd за ту годину. Аутор првог је војвођански писац и преводилац Габор Тури (Túri Gábor, рођен 1955. године) који у свом тексту под насловом Мохиканаи, книжевноі йревођень веома детаљно и акрибично анализира Ачева преводилачка решења, а затим извлачи поуку која би могла бити актуелна и данас. Тури, наиме, наглашава да нашој култури (Тури мисли и на мађарску и на југословенску културу тог времена) и даље недостаје једна „освешћена“ (ауто)поетика превода са „декодираном методологијом“ у којој би аутори открили и систематизовали тајне властите преводилачке радионице. (Túri 1985: 1504-1505). Аутор другог - могло би се рећи и паралелног - приказа ове важне антологије Кароља Ача, критике под насловом Немерљивосӣ ирревоgа јесте Сава Бабић. По његовом мишљењу, изузетно високи квалитет Ачевих препева не произлази само из врхунске креативности преводилачких решења - а Бабић наводи довољан број упечатљивих примера да нас у то увери - већ и из чињенице што Карољ Ач књижевне преводе није напросто механички придодао низу својих оригиналних песничких остварења, већ их је свесно, органски уградио у свој властити опус. (Babić 19856: 1509).

Наредна, 1986. година, поново је година значајног јубилеја, 150 година од објављивања антологије превода Szerb népdalok és hösregék (Српске народне песме и јуначке приче) Јожефа Секача (Székács József, 1809-1876), што је својевремено био и пионирски подухват приближавања српске народне епике мађарској читалачкој публици. Тим поводом, у тексту под насловом На іодишњииу објавтивать анйотоїuje „Szerb népdalok és hösregék“, Имре Бори се осврће на Секачеву књижевну и просветитељску делатност и животни пут, а о самим преводима каже следеће: „Истина је да су његови преводи застарели, као што су застарели готово и сви други преводи настали у тој епохи, будући да је велика већина њих достигла тек одређени стандарднојезички ниво, али без језичко-стваралачког замаха или песничког надахнућа." (Bori 1986: 615).

Непуних годину дана касније стиже и добро утемељен, прикривено полемички одговор на овај вредносни суд који је о Секачевим преводима изрекао Имре Бори. Аутор 
те студије под насловом O gелу Јожефа Секача је академик Иштван Сели (Szeli István, 1921-2012). Сели поставља реторичко питање има ли смисла један сто педесет година стари превод мерити данашњим поетичким и естетичким аршинима и, како би поткрепио своју тезу да то не би требало да буде тако, наводи пример два мађарска превода Пушкиновог Евїенија Оюеіина. Сели упоређује стари, деветнаестовековни превод Кароља Берција (Bérczy Károly, 1821-1867) са новијим преводом модерног песника Лајоша Априлија (Áprily Lajos, 1887-1967) и, мада признаје да Берцијев превод проговара на знатно једноставнијем, упрошћенијем језику, он ипак данашњим читаоцима пружа јединствени увид у неке језичко-стилске карактеристике једне прохујале епохе, а тиме што обогаћује текст „(...) акустиком пушкиновског говора, бидермајерска атмосфера мађарског текста даје Берцијевом преводу једну додатну вредност која модерну верзију не одликује." (Szeli 1987: 415).

У октобарском броју часописа исте, 1987. године, Ђерђ Пап у тексту под насловом Сйо хиљаgа мађарских речи „Хазарскоі речника“ осврнуо се на мађарски превод Хазарскоі речника Милорада Павића. Мађарски преводилац те књиге и сам је познати војвођански писац Иштван Брашњо (Brasnyó István, 1943-2009). Ђерђ Пап с правом сматра ово Павићево дело великим „залогајем“ чак и за најискусније и најдаровитије преводиоце. И премда у својој детаљној анализи Пап налази неколико значајних огрешења о оригинал, у целини гледано, Брашњов превод оцењује као врло добар. (Рарр 1987: 1325-1330).

И коначно, али никако на последњем месту, требало би поменути и пример лепе праксе часописа Híd да своје бројеве посвећене различитим књижевним годишњицама посвећује не само одавно преминулим књижевницима (тај случај смо видели на примеру стогодишњице Костолањијевог рођења и сто педесете годишњице Секачевих превода српске епике), већ и живим и активним књижевницима који су у мађарској (али и у српској) култури својим дотадашњим радом оставили значајан траг. Управо у духу те добре традиције, Híd је свој априлски број 1991. године посветио тридесетогодишњици 
преводилачке, есејистичке и педагошке делатности Саве Бабића, књижевника, интелектуалца и универзитетског професора који је својим неуморним преводилачким, научним и есејистичким радом значајно задужио и српску и мађарску културу. У овом броју нашао се и зналачки и веома позитиван приказ Бабићеве књиге есеја о преводилачком чину. Приказ је дело Еве Толди (Toldi Éva, рођена 1962. године) и у њему се ауторка бави Бабићевом збирком есеја Пети више $\bar{u} e \bar{u}$. (Toldi 1991: 398-400). ${ }^{1}$

Посебно се, у овом броју часописа посвећеном Сави Бабићу, истиче надахнут есеј песника Ота Толнаија (Tolnai Ottó, poђен 1940. године) који заправо представља текст отварања будимпештанске изложбе слика суботичког сликара и писца Имреа Шафрања (Sáfrány Imre, 1928-1980), посвећене како Шафрању, тако и Бабићу. Занимљиво је да је Шафрањ управо и аутор прве књиге коју је Сава Бабић превео с мађарског на српски. Иако Толнаијев есеј није транслатолошка

1 У овом чланку фокусирали смо се само на есејистичке и теоријске радове који су у датом периоду објављивани у часопису Híd, али свакако се мора нагласити да су стални и повремени сарадници овог часописа, као и његови уредници, и те како водили рачуна и о томе да правовременим и зналачким приказима испрате најновију продукцију на плану теоријских књига из области транслатологије, како у Југославији, тако и у Мађарској. Тако је на мађарски превод књиге Теорија йревођењь словачког транслатолога Антона Поповича (Anton Popovič, 1933-1984) детаљним приказом под насловом

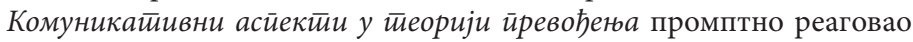
Александар Рончак (Roncsák Alekszandár). (Roncsák 1982: 273-275). Исте године Ђерђ Пап се у студиозном приказу под насловом Какво

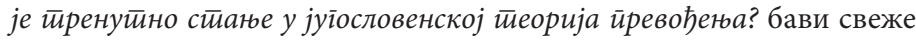
објављеним зборником радова Теорија и йоейика йревођена који је уредио Љубиша Рајић. (Рарр 1982: 530-536). А није прошла, наравно, незапажено ни обимна књига Како смо иревоgили Петефбија Саве Бабића, коју су приказали и Иштван Сели у тексту под насловом „Тако смо ӥревоgили Пететефија“ (Szeli 1986: 832 - 839), и Габор Тури у приказу под насловом Превоgи Пет̄ефија (Túri 1986: 840-843). И управо исти тај број часописа Híd, у доброј мери посвећен теорији

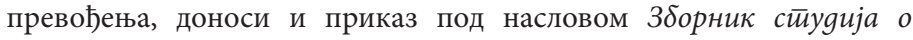
йийанима ӣревођень из пера Валерије Балаж-Арт (Balázs-Arth Valéria), у којем се ауторка осврнула на збирку радова светски признатих транслатолога, преведених на мађарски и објављених у Будимпешти. (Balázs-Arth 1986: 1247-1251). 
студија у строгом смислу те речи, овај песник ипак духовито и луцидно примећује неке важне карактерне особине Саве Бабића, не само као преводиоца, већ и као културног посленика, човека који своју мисију популарисања мађарске књижевности и представљања одређених, себи блиских писаца, српској и југословенској публици, схвата не као занат, већ као мисију и личну интелектуалну авантуру. Ево како Толнаи то види: „Сава је у то време [почетком шездесетих година - напомена М. Ч.] произвео своју прву књигу (...) кажем то тако због тога што он ни касније није тек писао и преводио своје књиге. Сава има ту способност да направи паклени ковитлац око писца. У случају Шафрања, реч је о аутору чије место у књижевности ни у то време, а заправо ни данас, није прецизно утврђено. (...) Преводећи и тумачећи писце, Сава покушава да их уведе у нову средину, а у његовом случају, то слободно могу рећи, да их тамо прошверцује, прокријумчари.“ (Tolnai 1991: 415-416).

У истом броју огласио се и сам слављеник Сава Бабић још једном студијом из властите преводилачке радионице под насловом Превоgийи - свакако; менайи - сме ли се? У њој Бабић детаљно разрађује неке дилеме са којима се суочио приликом превођења комплексног псеудокриминалистичког кратког романа Jegноухи (A félfülü) нашој публици одраније познатог модерног класика Тибора Дерија (Déry Tibor, 1894-1977). У овој студији Сава Бабић креативно разрађује једну, рекло би се, прастару преводилачку дилему, а она гласи: шта радити са културним реалијама, са информацијама или алузијама које су општепознате и бремените значењем за публику изворног језика, док читаоцима циљног језика не значе практично ништа. Одбацујући фусноту као својеврсну капитулацију преводиоца, Сава Бабић наводи да би старинско, а данас већ одбачено решење „преводилачког одомаћивања“ ипак у неким ситуацијама могло да се примени. Он наводи неколико занимљивих примера за такву могућност, а најупечатљивији је свакако пример када се у оригиналу наводи име легендарне мађарске глумице Мари Јасаи (Jászai Mari, 1850-1926). И мада у Будимпешти постоји трг који је назван по њој, њено име великој већини 
наших читалаца не говори много. Стога у таквим, ретким, ситуацијама, Сава Бабић предлаже поступак „одомаћивања“ односно замену дате реалије неким домаћим адекватом. У том смислу би, по његовом мишљењу, у српском преводу уместо Мари Јасаи могла да се нађе Жанка Стокић, а у хрватском, рецимо, Жужи Јелинек. (Babić 1991: 370-371).

Свакако да се и у наредне три деценије, све до наших дана, часопис Híd својски трудио да одржи традицију повременог објављивања текстова који се теоријски и/или поетички баве самим процесом превођења. Ипак, њихов детаљнији приказ и коментар захтевао би најмање још један прегледни рад овог типа и сличног обима. Осим тога, 1991. година јесте свакако важна прекретница, имајући у виду велике промене које су, распадом бивше Југославије, задесиле и мађарску књижевност у Војводини. Стога су деведесете године више протекле у знаку присећања на „стара добра времена“ теорије и праксе превођења, да би почетком двехиљадитих полако почели да се јављају и нови гласови. Но, с обзиром на цезуру коју је 1991. година представљала, уследиће и значајна промена перспективе и парадигме, што ће утицати и на природу и методологију, па и на стил текстова о превођењу. Анализу отежава и недостатак одговарајуће историјске дистанце, али и чињеница да је, поред осталих, и сам аутор овог чланка делимично допринео тој промени транслатолошке парадигме у часопису Hid, нарочито после 2010. године. Није искључено да у будућности, у оквиру проучавања војвођанске мађарске транслатологије у периодици, буде и таквих истраживања. Писац ових редова таква потенцијална истраживања, наравно, с нестрпљењем очекује.

\section{Извори и литература}

Babić, Sava 1973. „Petőfi szerbhorvátul”. Híd, 1973/3-4., стр. 17-19. Babić, Sava 1977. „Veljko Petrović magyar fordításai“. Híd, 1977/10., стр. 1229-1235.

Babić, Sava 1985a. „Búcsú a csodáktól: az »alkotói« idézetek fordítási nehézségei“. Híd, 1985/3., cтp. 377-385. 
Babić, Sava 19856. „A fordítás mérhetetlensége“. Híd, 1985/11., стр. 1505-1520.

Babić, Sava 1991. „Fordítani - okvetlenül; változtatni - szabad-e?“. Híd, 1991/4., 368-372.

Balázs-Arth Valéria 1986. „Tanulmánykötet a fordítás kérdéseiről”. Híd, 1986/10., стр. 1292- 1293.

Bori Imre 1975. „Ivo Andrić művészete a magyar irodalom tükrében”. Hid, 1975/9., стр. 799-811.

Bori Imre 1977. „Ady Endre a szerbhorvát irodalomban (1906-1944)“. Híd, 1977/1., стр. 54-71.

Bori Imre 1986. „A Szerb népdalok és hősregék évfordulóján“. Híd, 1986/5., стр. 613-619.

Papp Tibor 1972. „Nyelvek irodalma - az irodalom nyelve”. Híd, 1972/5., стр. 652-659.

Papp György 1982. „Hol tart a jugoszláv fordítástudomány?”. Híd, 1982/4., стр. 530-536.

Papp György 1983. „Egy különös ajándék“. Híd, 1983/4., стр. 525-530.

Papp György 1985. „Pacsirta idegenben. Egy Kosztolányi-regény szerbhorvát kiadásának fordítástörténeti tanulságai”. Híd, 1985/10., стр. 1355-1362.

Papp György 1987. „A kazár szótár százezer magyar szaváról“. Híd, 1987/10., стр. 1325-1330.

Roncsák Alekszandár 1982. „Kommunikációs szempontok a müfordításelméletben”. Híd, 1982/2., 273-275.

Szeli István 1986. „Így fordítottuk Petőfit”. Híd, 1986/6., стр. 832-839.

Szeli István 1987. „Székács József művéről”. Híd, 1987/3., стр. 414-416.

Szücs Imre 1974. „Költői párhuzamok“. Híd, 1974/3., стр. 349-360.

Toldi Éva 1991. „Irodalom - sajátos nézőpontból”. Híd, 1991/4., стр. 398-400.

Tolnai Ottó 1991. „Sava salabaktere (A Sava Babić munkásságát bemutató budapesti tárlat megnyitószövege)“. Híd, 1991/4., 415-419.

Tóth Tamás 2010. „A kultúrák közötti kommunikáció kérdésétől a »fordítás modelljéig«“. У: Jeney Éva (yp.) 2010. Szó és betü szerint a világ. Budapest: Balassi Kiadó, стр. 131-159.

Túri Gábor 1985. „A müfordítás mohikánja”. Híd, 1985/11., стр. 14991505.

Túri Gábor 1986. „Petőfi-fordítások“. Híd, 1986/6., 840-843.

Végel László 1976. „A fellázadt ember reménye”. Híd, 1976/2., стр. 1350-1354. 


\section{Marko Čudić}

\section{THEORY OF TRANSLATION AND TRANSLATION CRITICISM IN THE LITERARY JOURNAL HIID FROM 1972 UNTIL 1991}

The Novi Sad-based literary journal Híd, during its 85 years of existence, has grown into the most significant literary and cultural printed media of the Hungarians from Vojvodina. Apart from following the current Hungarian literary production in Vojvodina, the journal regularly publishes Hungarian translations of contemporary Serbian literature. The aim of this paper is to offer a systematic chronological overview of translatology-centred texts published in this journal from 1972 until 1991.

Key Words: Híd literary journal, scientific and essayistic thought on translation. 